\title{
The Contribution of Lecturer Pedagogical Competence, Intellectual Intelligence and Self-Efficacy of Student Learning Motivation
}

\author{
Panni Ance Lumbantobing \\ Sari Mutiara University, Indonesia \\ panniance@yahoo.com
}

\begin{abstract}
This study aims to investigate the contribution lecturers' pedagogical competences, intellectual intelligence and self-efficacy of student learning motivation. The analysis technique in this study is a multiple regression and comparison technique. It observes the relationship or influence among three variables. The sample of this study consisted of 30 students. The validity test results for each variable of lecturer pedagogical competence, intellectual intelligence, self-efficacy, and student learning motivation are valid, while the reliability of each variable is all reliable. The research findings show that the results of the analysis obtained the price of Fhit $=371,862, d b=(3.26)$, $p$-value $=0,000<0.05, \mathrm{Ho}$ is rejected. The price of $R 2=0.977$, Fhit $=371,862, d b=(3.26) p$ value $=0,000<0.05$ or $\mathrm{Ho}$ is rejected. The contribution of lecturers 'pedagogical competence, intellectual intelligence and self-efficacy to students' learning motivation is 0.977 or $97.7 \%$. Thus, lecturers' pedagogical competence, intellectual intelligence and self-efficacy simultaneously influence student learning motivation.
\end{abstract}

\author{
Keywords \\ pedagogical \\ competence; \\ intellectual intelligence;

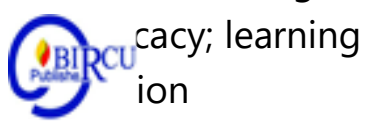

\section{Introduction}

The rapid development of science and technology leads to people to be able to take advantage of science and technology. One of the factors that determine the success in the learning process is learning motivation. The success of an education is influenced by student motivation. Effective learning conditions are the motivation of students in learning. Motivation is very closely involved in encouraging someone to get their goals. Motivation is very much needed in the teaching-learning process.

Students who have high motivation will be seen through their actions or activities in achieving achievement or learning goals. Student motivation has a great opportunity to encourage them to improve their competence and compete to achieve maximum results in learning. Good motivation in learning shows good results. In other words, by having high motivation, it produces good achievements. In learning activities, motivation can be said to be the overall driving force within students which ensures the continuity of learning activities and gives direction to learning activities, so that the desired goals can be achieved.

University students are individuals who study within the scope of higher education. In the process of learning in tertiary institutions, motivation has a close relationship with increasing learning outcomes, commonly known as grade point average. Learning motivation is an active driver in students to carry out activities learning. It directly determines the intensity of learning. A student who has high learning motivation carries out learning activities optimally (Sardiman, 2003). 
Sari Mutiara University of Indonesia is one of the universities entrusted with the duty and responsibility to create and build generations of nations that have superior quality human resources and are able to compete with the best competencies in society. The role of students as agents of change is expected to have a role or great benefits to society as a whole for the development of quality in environment.

The facts on the field can be seen that there are still many students majoring in primary school teacher education at Sari Mutiara University of Indonesia who do not have the motivation or desire of themselves to succeed. This can be seen through the large number of students who eventually drop out of college, students who are not serious in conducting lectures, students who do not care about the advancement of their personality competencies, students who are willing to get the status of Eternal Students on campus and overall these types of students have learning outcomes tend to be lower than other students who still have motivation in the lecture process, even students who are only aggressive to get high grades without caring whether they have really achieved the expected knowledge. Other facts are also found within the scope of campus life, there are still found students who initially have the motivation to learn, but because of the influence of the campus can cause the motivation of a student to be lost.

Preliminary research is conducted to observe the condition of students in October 2019, they do not have a good grade point average. The motivation of each student to get the results of study is different, there are those who study earnestly and others do not pay attention of their study. In fact, the learning outcomes that they have received, it is rare to evaluate the continuity between the knowledge and attitudes. Learning outcomes are the final assessment of students seen through each of their knowledge competencies and attitudes

Many factors can affect student motivation. One of them is the pedagogical ability of lecturers. It directly has a very big influence on student motivation. If the lecturer can deliver the lessons in accordance with the expectations of students, it makes the teaching and learning process run effectively and efficiently. Mulyasa (2012:75) Pedagogic competence is the ability to manage learning process which includes understanding of students, designing, implementing, and evaluating learning outcomes and developing students to actualize their various potentials.

In addition to lecturer pedagogical competence, internal factor that influence student learning motivation is intellectual intelligence. The intelligence factor is one of the intrinsic factors of learning achievement. It is intellectual ability, analysis, logic and ration. Intellectual Intelligence is the intelligence to receive, store and processing information into facts. It is the ability needed to perform various mental activities of thinking, reasoning and problem solving.

Other internal factor that influences student learning motivation is self-efficacy. it is a form of a person's belief in his ability to control the potential that exists in himself. Efficacy plays a very important role in daily life, a person will be able to use his potential optimally if self-efficacy supports him, and one aspect that is influenced by self-efficacy is learning motivation. Self-efficacy can affect one's interest in something that is positive about something that is believed. It can be a determinant of success in carrying out work, influencing mindset and emotional reactions in decision making. A belief that exists in an individual affects the success of a job and it also affects the individual in making decisions. 


\section{Review of Literature}

\subsection{Learning Motivation}

Motivation and learning are two things that cannot be separated and influence each other. Learning is a change in behavior that is relatively permanent and potentially occurs as a result of practice or reinforcement based on the goal to achieve certain goals. Motive can be said as a driving force to do certain activities in order to achieve a goal. Sardiman (2011:71) says that motivation is a change in energy in a person that is characterized by the appearance of "feeling" and preceded by a response to the existence of goals.

Uno (2011:23) Learning motivation is internal and external encouragement to students who are learning to conduct behavior, in general with several indicators or supporting elements. These indicators include desire to succeed, encouragement and needs in learning, hopes and ideals of the future, appreciation in learning, and conducive learning environment. Winkel (2005: 160) learning motivation is the overall psychic driving force in students that causes learning activities in order to achieve a goal. Indicators of a person's motivation according to Uno (2009:31) include: (1) the existence of a desire to succeed, (2) encouragement and needs in learning, (3) appreciation in learning, (4) the existence of interesting activities in learning, and, (5) the existence of a conducive learning environment.

Based on the description above, it is concluded that learning motivation is a force that encourages students to do certain activities in order to achieve a goal. Indicators of learning motivation are the desire to succeed and there is encouragement and need in learning.

\subsection{Self Efficacy}

Students who have high self-efficacy tend to be able and confident to face the difficulties encountered in learning. Self-efficacy leads us to set challenging ideals and persist in difficulties. When problems arise, strong feelings of self-efficacy encourage students to stay calm and find solutions rather than reflecting on their inability.

Ormrod (2008:20) self-efficacy is an assessment of someone about his own ability to carry out certain behaviors or achieve certain goals. It is self-confidence about the ability to carry out tasks in certain contexts. Gregory (2011) defines self-efficacy as self-confidence to find out ability in order to carry out a form of control over the benefits of the person and the events in the surrounding environment. Confidence in one's own ability influences personal motivation, the higher the belief in one's own ability, the stronger the determination to complete the task well. Not only the ability to work determines the success of the task, but also determined by the level of confidence in the ability so that it can increase the intensity of motivation.

Based on the explanation above, it is concluded that self-efficacy is a belief that a person has about his ability to act to achieve the goal, with indicators of confidence in involvement in the task, and confidence in his ability to withstand challenges.

\subsection{Intellectual Intelligence}

Intelligence is a general ability to deal with and adapt to the demands of the environment. Intelligence directs a person to achieve success in the academic field. Intellectual intelligence is the qualification of human intelligence that is dominated by the 
ability of rational and logical thinking. It is seen from the ability of logic, analysis, and someone's ratio. Kuswana, (2014:141) intelligence is the ability of individuals to provide an appropriate response to the stimulus they receive. While learning from experience, thinking using metacognitive processes, and the ability to adapt to the surrounding environment.

Intelligence as the ability to learn from experience, think using cognitive processes, and the ability to adapt to the surrounding environment. Intellectual intelligence is the ability to analyze, logic and one's rationale. Thus, this is related to speech skills, intelligence of space, and awareness of something that appears. Goleman (2003:57) intellectual intelligence is the ability needed to carry out mental activities, thinking, reasoning and solving problems .Buchori (2016: 198) intellectual intelligence is a mirror of logical and verbal intelligence, so people who have high intellectual intelligence are generally successful in education. Susanto (2007) defines intellectual intelligence as a person's ability to acquire knowledge, master and apply it in the face of problems. Fudyartanta (2004) the indicators of intellectual intelligence that are the ability to solve problems, to show knowledge about the problems faced, to take appropriate decisions, to solve problems optimally and to show clear thoughts.

Based on some definitions above, it is concluded that intellectual intelligence is the ability of a person to gain knowledge, master and apply it in dealing with problems. Indicator of Intellectual Intelligence are the ability to solve problems, to show knowledge about the problems faced, to take appropriate decisions, to solve problems optimally, and to show clear thoughts.

\subsection{Lecturer Pedagogical Competence}

Pedagogic competence is an understanding of learners and management of learning, which is useful for knowing the characteristics of students in order to know the need of students. Pedagogic competence is the ability to manage student learning. Based on Law No. 14 of 2005 concerning Teachers and Lecturers explains that the pedagogical competence is the ability of a teacher and lecturer in managing the learning process related to students, including understanding insight or educational foundation, understanding of students, curriculum or syllabus development, learning design, implementing learning educate and dialogue, use of learning technology, evaluation of learning outcomes, and development of students to actualize the various potentials they have.

Mulyasa (2012:26) the competence of lecturers is a combination of personal, scientific, technological, social, and spiritual which includes mastery of the material, understanding of students. Shah (2000:230) Competence is the ability, skills, circumstances authorized, or fulfilling the requirements according to legal provisions. Furthermore, it is the ability of a teacher to carry out his responsibilities responsibly and properly.

Lecturers should realize that teaching is not an easy job. Instead, teaching is very complex because it involves pedagogical, psychological, and didactic aspects simultaneously. The pedagogical aspect shows the fact that teaching takes place in an educational environment. Kunandar (2009:76) pedagogical abilities include understanding lecturers of students, designing and implementing learning, evaluating learning outcomes, and developing students to actualize their various potentials. Janawi (2011:75) pedagogical competences are the ability to manage learners which includes an understanding of learning design and implementation, evaluation of learning outcomes, and student development. 
Based on the above theory, it is concluded that the lecturer pedagogical competence is the ability to understand students in depth and the organization of learning that educates. An understanding of learners includes an understanding of developmental psychology, while educative learning includes the ability to design, implement, assess the process of learning outcomes and make continuous improvements.

\section{Research Methodology}

\subsection{Place and Time of Research}

This research is conducted at Sari Mutiara University of Indonesia in Medan. The choice of this place is based on consideration of the ease of obtaining data. Tthe researcher focuses more on the problem to be studied. The time of this research is conducted in October to December 2019. The study population is students of Sari Mutiara Indonesia University majoring in elementary school teacher education which consisted of 78 students and it takes 30 students as a sample in this study.

\subsection{Types of Research}

To conduct a research is needed an appropriate research method to obtain conclusions. The use of research methods is adapted to the objectives and research situation so that it can be determined the tools or techniques used. The method used in this study is ex Post Facto research method because events that have occurred then retreat to find out the causes.

\subsection{Data Analysis Technique}

The analysis technique used in this research is the technique of multiple regression and correlation, which observes the relationship or influence between two or more variables The variables in this study consisted of three independent variables, namely lecturer pedagogical ability (X1), Intellectual Intelligence (X2) and Self-Efficacy (X3) and one dependent variable namely Student Learning Motivation (Y). To test the hypothesis used with the help of a SPSS computer program for Windows version 25.0. In testing the hypothesis used a significance level of $\alpha$ of 0.05 .

\subsection{Research Result}

This study aims to determine the contribution of lecturers pedagogical competences, intellectual intelligence, and self-efficacy to student learning motivation by using Multiple Regression.

Hypothesis 1:

$\mathrm{H}_{0}: \beta_{1} \leq 0$

$\mathrm{H}_{1}: \beta_{1}>0$

$\mathrm{H} 0=$ lecturer pedagogical competence does not have a positive influence on learning motivation

$\mathrm{H} 1$ = lecturer pedagogical competence has a positive influence on learning motivation Hypothesis2:

$\mathrm{H}_{0}: \beta_{2} \leq 0$

$\mathrm{H}_{1}: \beta_{2}>0$

$\mathrm{HO}=$ Intellectual intelligence does not have a positive influence on learning motivation 
$\mathrm{H} 1$ = Intellectual intelligence has a positive influence on learning motivation Hypothesis 3:

$\mathrm{H}_{0}: \beta_{3} \leq 0$

$$
\mathrm{H}_{1}: \beta_{3}>0
$$

$\mathrm{HO}=$ self-efficacy does not have a positive influence on learning motivation

$\mathrm{H} 1$ = self-efficacy has a positive influence on learning motivation.

The description of the data presented in this section includes variables of lecturer pedagogical competence (X1), Intellectual Intelligence (X2) and Self-Efficacy (X3) and one dependent variable is Student Learning Motivation (Y). The data is the result of the quantification of respondents' answers to the questionnaire that distributed to students as shown in table 1 below.

\section{Descriptive Statistics}

\begin{tabular}{|l|l|l|l|}
\hline & Mean & Std. Deviation & $\mathrm{N}$ \\
\hline Learning Motivation & 7.30 & 1.442 & 30 \\
Lecturer Pedagogical Competence & 7.10 & 1.539 & 30 \\
Intellectual Intelligence & 24.40 & 3.470 & 30 \\
Self Efficacy & 14.50 & 2.047 & 30 \\
\hline
\end{tabular}

Based on the results of descriptive analysis obtained average variables: Learning Motivation $=7.30$, Pedagogical Ability $=7.10$, Intellectual Intelligence 24.40, and SelfEfficacy $=14.50$.

\section{Double Linear Equations and Test the Significance of Regression Equations}

Coefficients

\begin{tabular}{|c|c|c|c|c|c|c|c|c|}
\hline \multirow[t]{2}{*}{ Model } & \multicolumn{2}{|c|}{$\begin{array}{l}\text { Unstandardized } \\
\text { Coefficients }\end{array}$} & \multirow{2}{*}{\begin{tabular}{|l}
$\begin{array}{l}\text { Standardize } \\
\mathrm{d} \\
\text { Coefficients }\end{array}$ \\
Beta
\end{tabular}} & $\mathrm{t}$ & \multirow[t]{2}{*}{ Sig. } & \multicolumn{3}{|c|}{ Correlations } \\
\hline & $\mathrm{B}$ & Std. Error & & & & Zero-order & Partial & Part \\
\hline (Constant) & -3.315 & .323 & & -10.271 & .000 & & & \\
\hline $\begin{array}{l}\text { Lecturers } \\
\text { Pedagogical } \\
1 \text { Competence }\end{array}$ & .191 & .032 & .204 & 5.978 & .000 & .592 & .761 & .177 \\
\hline $\begin{array}{l}\text { Intellectual } \\
\text { intelligence }\end{array}$ & .138 & .026 & .333 & 5.378 & .000 & .906 & .726 & .159 \\
\hline Self Efficacy & .406 & .047 & .576 & 8.710 & .000 & .964 & .863 & .258 \\
\hline
\end{tabular}

a. Dependent Variable: Learning Motivation

Based on the coefficients table above, in column B is obtained the constant bo $=-3.315$, the regression coefficient $\mathrm{b} 1=0.91$, and $\mathrm{b} 2=0.138$, and $\mathrm{b} 3=0.406$. Thus the multiple linear regression equation is $=-3.315+0.191 \mathrm{X} 1+0.138 \mathrm{X} 2+0.406 \mathrm{X} 3$. 
Hypothesis 1:

$\mathrm{H}_{0}: \beta_{1} \leq 0$

$\mathrm{H}_{1}: \beta_{1}>0$

Based on the analysis results presented in the above table, it is obtained the price of $\mathrm{t} 1=$ 5.978 , p-value $=0.000<0.05$, or Ho is rejected. Thus, lecturer pedagogical competence has a positive influence on learning motivation.

Hypothesis 2:

$\mathrm{H}_{0}: \beta_{2} \leq 0$

$\mathrm{H}_{1}: \beta_{2}>0$

Based on the analysis results presented in the above table, the price of $\mathrm{t} 2=5.378$, $\mathrm{p}$ value $=0.000<0.05$, or Ho is rejected. Thus intellectual intelligence has a positive influence on learning motivation

Hypothesis 3:

$\mathrm{H}_{0}: \beta_{3} \leq 0$

$\mathrm{H}_{1}: \beta_{3}>0$

Based on the results of the analysis presented in the above table, the price of $\mathrm{t} 2=$ 8.710 , p-value $=0.000<0.05$, or Ho is rejected. Self-efficacy has a positive effect on learning motivation. The results of the analysis presented in the above table also show the partial correlation coefficient ry1.23. $=0761 ;$ ry2.13 $=0.726$; and ry.3.12 $=0.863$, which also has a p-value $<0.05$.

Significance Test of Regression Equations

\begin{tabular}{|l|l|l|l|l|l|l|}
\hline \multicolumn{2}{|l|}{ ANOVA $^{2}$ Model } & $\begin{array}{l}\text { Sum of } \\
\text { Squares }\end{array}$ & df & $\begin{array}{l}\text { Mean } \\
\text { Square }\end{array}$ & F & Sig. \\
\hline \multirow{3}{*}{1} & Regression & 58.927 & 3 & 19.642 & 371.862 & $.000^{\mathrm{b}}$ \\
\cline { 2 - 8 } & Residual & 1.373 & 26 & .053 & & \\
\cline { 2 - 8 } & Total & 60.300 & 29 & & & \\
\hline
\end{tabular}

a. Dependent Variable: Learning Motivation

b. Predictors: (Constant), Self Efficacy, Lecturer Pedagogical Competence,

Intellectual Intelligence

Based on the analysis results obtained by Fhit $=371,862, \mathrm{db}=(3.26), \mathrm{p}$-value $=0,000$ $<0.05$, Ho is rejected. Thus, lecturers' pedagogical competence, intellectual intelligence and self-efficacy simultaneously have an influence on student motivation.

Test the Significance of Multiple Correlation Coefficients Model Summary

\begin{tabular}{|l|l|l|l|l|l|}
\hline Mode & $\mathrm{R}$ & $\mathrm{R}$ & Adjust & Std. Error & Change Statistics \\
\hline
\end{tabular}




\begin{tabular}{|l|l|l|l|l|l|l|l|l|l|}
\hline 1 & & $\begin{array}{l}\text { Squar } \\
\text { e }\end{array}$ & $\begin{array}{l}\text { ed R of the } \\
\text { Square }\end{array}$ & $\begin{array}{l}\text { R } \\
\text { Estimate }\end{array}$ & $\begin{array}{l}\text { Square } \\
\text { Change } \\
\text { Change }\end{array}$ & df1 & df2 & $\begin{array}{l}\text { Sig. F } \\
\text { Change }\end{array}$ \\
\hline 1 & $\begin{array}{l}.98 \\
9^{\mathrm{a}}\end{array}$ & .977 & .975 & .230 & .977 & $\begin{array}{l}371.86 \\
2\end{array}$ & 3 & 26 & .000 \\
\hline
\end{tabular}

a. Predictors: (Constant), Self Efficacy, Lecturer Pedagogical Competence , Intellectual intelligence

Based on the analysis results presented in the table above, it is obtained the price of $\mathrm{R} 2=$ 0.977 , Fhit $=371,862, \mathrm{db}=(3.26)$, p-value $=0,000<0.05$ or Ho is rejected. Thus, lecturer pedagogical competence, intellectual intelligence and self-efficacy simultaneously have an influence on student learning motivation. From the results of the analysis presented in the table above, the price $\mathrm{R} 2=0.977$, Fhit $=371,862, \mathrm{db}=(3,26)$; $\mathrm{p}$-value $=0,000<0.05$ or Ho is rejected. The contribution of lecturer pedagogical competence, intellectual intelligence and self efficacy to student learning motivation is 0.977 or $97.7 \%$.

\section{Discussion}

The results of this study partially indicate that the lecturer pedagogical competence, intellectual intelligence and self-efficacy simultaneously have an influence on student motivation, namely Fhit $=371,862, \mathrm{db}=(3,26)$; $\mathrm{p}$-value $=0,000<0.05$ or Ho is rejected. It implies an increase the variables of lecturer pedagogical competence, intellectual intelligence and self-efficacy simultaneously increase student motivation. With lecturer pedagogical competence, intellectual intelligence and self-efficacy increase student motivation. Learning motivation is the result of a person's achievements towards how well his learning provides something useful to him. Learning motivation as a general attitude towards one's learning activities. Learning motivation can be viewed from psychological, physical, social, job security, opportunities to progress and develop which all of that can be improved by increasing the variables of lecturer pedagogical competence, intellectual intelligence and selfefficacy.

In reality, lecturer has not played an effective role in supervising students. The results of the study show that the low pedagogical ability of the lecturer is influenced by internal factors, namely the ability and motivation of students, and external factors are influenced by self-efficacy. (Srinalia, 2015) self-confidence is to know their abilities so they can exercise some form of control over the benefits of themselves and the events in the surrounding environment.

The high perceived self-efficacy increases individual cognitive learning motivation to act appropriately and directed, especially if the achieved goal is a clear goal. The individual's mind on self-efficacy determines how much effort is expended and how long the individual persists in the face of obstacles or unpleasant experiences. Self-efficacy is always related and has an impact on the choice of behavior, motivation and persistence of individuals in dealing with each problem. The more aspects of work that are in accordance with individual desires, the higher the level of student learning motivation is felt.

Furthermore, the significance test results indicate the magnitude of the influence between the lecturer pedagogical competences on learning motivation. This is the same as the statement of Suryabrata (2011) the effective behavior of lecturers, pedagogical ability can 
make students more motivated to learn. This condition encourages students to put high trust in the lecturers so that they can help face difficulties in the lecture and social processes in the campus environment. Lecturers who have such personalities can be one of the factors that encourage students to learn more enthusiastic, better, and more responsible.

Likewise lecturers who are able to explain the material well, have sufficient preparation, master all the material, and master the latest issues related to the subject matter, are able to arrange the material sequentially. The ability of lecturer makes students have awe, respect, easy to get the point of the material and enthusiasm in attending the lecture process. Students have been motivated to learn by following a fun learning process. Sardiman (2008: 92-95) to foster student motivation, lecturers must increase their competition in teaching so that it can be used as a tool to increase student motivation.

It is line with Balqis(2014) students' perceptions about the pedagogical competence of educators having an influence on learning motivation. This can happen because the lecturer gives students the opportunity to be actively involved in using information and communication technology facilities in achieving learning objectives, communicating effectively, empathically, and politely with students is done every working day. It improves student behavior and takes reflective actions to improve the quality of learning carried out.

\section{Conclusion}

Based on the results of data analysis and discussions, there is an effect of lecturers pedagogical competence, intellectual intelligence and self-efficacy on the learning motivation of students at Sari Mutiara University of Indonesia which includes as high categories. There is a positive influence between lecturers pedagogical competence on learning motivation. It means that the higher pedagogical ability of lecturers have, the higher learning motivation the students have. There is a positive influence between intellectual intelligence on learning motivation which means that the higher the intellectual intelligence, the learning motivation will increase. There is a positive effect between self-efficacy on learning motivation which means that the higher the self-efficacy, the learning motivation will increase.

\section{References}

Balqis, P., Usman, N., \& Ibrahim, S. (2014). Teacher's pedagogical competence in increasing student motivation in junior high school 3 wants to triumph in Aceh's large district, Journal of Educational Administration, 2, (1) 25-38.

Buchori, B. (2016) Superior Brain: Tips for Increasing Brain Intelligence, Yogyakarta: Psychopedia.

Fudyartanta, K. (2004). Talent Test and Scaling of Intelligence. Pustaka Belajar, Yogyakarta. Goleman, D. (2003). Emotional Intelligence. Jakarta: Gramedia Pustaka Utama.Gregory J.

Feist and Feist, Jess. (2011). Personality Theory. Jakarta: Selemba Humanika.

Kunandar (2009). Professional Teacher Implementation of Education Unit Level Curriculum (KTSP) and Success in Teacher Certification. Jakarta: Rajawali Press.

Janawi (2011). Teacher Competencies Citra Professional Teachers. Bandung: Alfabeta.

Kuswana, W.S (2014) Behavioral Learning Biopsychology, Bandung: Alfabeta,

Mulyasa, E (2012) Competency Standards and Teacher Certification, Bandung: PT. Raja Rosadakarya. 
Ormrod, Jeanne. Ellis (2008). Educational Psychology Developing Learners Sixth Edition (Educational Psychology Volume 2, 6th Edition). Subtitles: Amitya Kumara. Jakarta: Erlangga.

Sardiman (2003). Teaching Learning Interaction \& Motivation. Jakarta: Rajagrafindo Persada.

Sardiman, A.M. (2008). Interaction and Teaching and Learning Motivation. Rajawali Press, Jakarta.

Srinalia. Factors causing the low performance of teachers and their correlation with student coaching: Case study at SMAN 1 Darul Imarah Aceh Besar. Didactic Scientific Journal February 2015. VOL. 15, NO. 2, 193-207.

Suryabrata, Sumadi, (2011). Educational Psychology, Jakarta: PT. Raja Grafindo Persada.

Suyanto (2007). Artificial Intelligence Searching, Reasoning, Planning and Learning. Publisher: Informatics. Bandung.

Shah, Muhibbin. (2000). Educational Psychology with a New Approach. Bandung: Remaja Rosdakarya.

Uno, Hamzah B. (2010).Educational Profession (Problems, Solutions, and Educational Reform in Indonesia). Jakarta: Earth Literacy

Uno, Hamzah B. (2011). Motivation Theory and Measurement: Analysis in the Field of Education. Jakarta: Bumi Aksara.

Winkel.W.S. (2005). Teaching Psychology. Jakarta: PT. Grasindo. 